Yuriy Zaliznyak

Doctor PhD of philology,

associate professor of New media department

Ivan Franko National University of Lviv,

jzalizniak@yahoo.com

\title{
AMERICAN PRINT PRESS ABOUT UKRAINIAN PRESIDENT'S INAUGURATION: IN-DEPTH ANALYSIS OF STORY COVERAGE SUFFICIENCY
}

\section{(C) Zaliznyak Yuriy, 2020}

The article is targeted at the examination of quantitative and qualitative characteristics of the articles in the US print media - dedicated to the inauguration of Volodymyr Zelensky as Ukraine's new President in May 2019. In this paper the author is describing particular traces of analytical reporting and prognosis performed by American print press authors covering international political issues. The matter of interest here is obvious after the appearance of Ukraine and country's new president as a disturbing factor for the US political life - taking into consideration Donald Trump's unsuccessful impeachment process. There are five print versions of well known in the US and worldwide newspapers in the focus of the research - The New York Times, The Washington Post, The Wall Street Journal, Chicago Tribune and USA Today. All of them are in top-10 popular print media in the country but at the same time have different editorial concepts from the point of view of their audiences' key news interests.

Key words: American print press; international political journalism; Ukrainian presidential elections; inauguration; Russian aggression; democracy; oligarchy.

Юрій Залізняк

\section{АМЕРИКАНСЬКА ДРУКОВАНА ПРЕСА ПРО ІНАВГУРАЦІЮ ПРЕЗИДЕНТА УКРАЇНИ: ГЛИБИННИЙ АНАЛІЗ ДОСТАТНОСТІ ВИСВІТЛЕННЯ ПОДІЇ}

Досліджено кількісні та якісні характеристики статей в американських друкованих медіа, які стосувались інавгурації Володимира Зеленського як нового Президента України у травні 2019 р. Описано окремі аспекти аналітичного репортерства i прогнозування авторів американських друкованих видань, які висвітлюють теми міжнародної політики. Актуальність теми очевидна після того, як Україна та її новий Президент стали фактором впливу на політичне життя у США, зважаючи навіть на невдалий процес імпічменту президента Дональда Трампа. У центрі уваги дослідження п'ять друкованих версій знаних у США та у світі газет - The New York Times, The Washington Post, The Wall Street Journal, Chicago Tribune тa USA Today. Усі вони входять до першої десятки найпопулярніших друкованих видань країни, але водночас сповідують різні редакційні концепції - 3 погляду ключових новинних інтересів їхньої аудиторії.

Ключові слова: американська друкована преса; міжнародна політична журналістика; вибори Президента України; інавгурація; російська агресія; демократія; олігархія. 
Introduction. The Ukrainian presidential elections in 2019 indicated some common features with the American presidential campaign of 2016. Here are just some of them: 1. the expected favorites had lost - Hilary Clinton in the US and Petro Poroshenko in Ukraine; 2. the winners were using similar rhetoric to consolidate their electorate - portraying themselves as people out of the current political system; 3 . both were massively exploiting social media along with particular media support (FOX news in the US and 1+1 TV channel in Ukraine) in their communication with the electorate; 4. Russian Federation factor was present as a matter of this country's specific interest when it comes to intervention into other communities' information and therefore political processes - in neighboring countries of former Soviet Union space and across the oceans.

The US media market as one of the biggest on the planet and its print media are constantly being used as a platform for political disputes on various issues. Ukrainian topic is also present here [1]. The story of significant political disruption in the Eastern European country that has obviously chosen western vector of development after the Revolution of Dignity in 2013-2019 [2] has to be obviously interesting to the American audience. The possible meaningful reasons here might be: Ukraine is neighboring country to Russia and is still under political, economical and military pressure from Moscow or its satellites as actual foes of the civilized world and the US in particular [3]; Ukrainian-US interactions are a matter of strategic partnership not only due to trade reasons but also due to security reasons after the Budapest memorandum was signed and Kyiv officially abandoned nuclear weapon in exchange for guaranties of safety from the US, the UK and Russia. Therefore, the question of professional reporters' analysis as journalism standard seems to be of the defining here - in order to understand capabilities of modern international journalism in predicting political implication of meaningful facts and foreseeing in quite a distant story possible effects for local (American) or global stories market.

For years The New York Times (NYT), The Washington Post, The Wall Street Journal, USA Today and Chicago Tribune are among top-10 American daily newspapers due to circulation statistics [4] and citation of their stories worldwide.

Our hypothesis is that each media tend to cover the same story standing on a separate ground of its editorial standards, audience's believed interests, proximity of the story implications to the US national interests. Another factor is availability of the particular newsroom's field correspondents and principles of a current "news flow" - as every story tends to have its own life cycle in a kaleidoscope of news industry routine.

The timeframe of the research is limited to 5 business days in the third decade of May 2019 - right after the president Zelensky's inauguration. Remembering that it is very hard for modern media and their audience to keep particular story interesting and fresh without actual evolution of some hot details, we have focused on national paper editions of each newspaper from May $20^{\text {th }}$ till May $24^{\text {th }}$. There has been a deliberate time lapse made after the second tour of elections - to give the reporters and other authors enough time for analytical materials preparation in between the new president's victory and his inauguration.

The methods used here are limited to quantitative, qualitative and content analysis - from the point of view of interpretive sufficiency principle [5]. There were several key indicators: importance of the story for the media's audience (location - number of pages and volume of coverage - the size or amount of articles on chosen story and mentions in other articles of the same newspaper); localization of reporters (Moscow or Kyiv); usage of Russian version Ukrainian capital transcription (Kiev) or Ukrainian one (Kyiv); in-depth analysis of the Volodymyr Zelensky as a political figure with a unique comic past - with close ties to particular oligarch in the corrupted for decades country, business interests in Russian Federation, against the background of ongoing Russian aggression and upcoming presidential elections in the US.

In our analysis we have deliberately chosen print editions of the newspapers as online sites of each media were able to publish the different (usually bigger) version of the story: due to obvious reasons not every online story is published in print but almost every print story has its online version. 


\section{Ukrainian elections in American press overview}

There have been some stories about Ukrainian elections, its participants and possible American ties published in the US media in between first, second tours and inauguration. Here we have the most vivid examples to my mind. For instance on April the $1^{\text {st }}$ Chicago Tribune has put two "Ukrainian" stories on its pages 8 and 9: the first one was dedicated to Joseph R. Biden's family corruption allegations connected to some Ukrainian energy company "Burisma Holdings" $[6 ; 8]$ and the second one - to the results of the first tour of presidential rally [7; 9].

The New York Times has demonstrated greater interest to these stories - as it has to be due to the paper's targeted audience. For example on March $17^{\text {th }}$, April the $1^{\text {st }}, 2^{\text {nd }}, 21^{\text {st, }}, 25^{\text {th }}$ and May the $2^{\text {nd }}$ and $17^{\text {th }}$ there have been several articles dedicated to Ukrainian elections on pages A9, A6, A9, A4, A1-A10-A11 and A6 respectively. The first profound article on $1 / 2$ of the page was focused on Mr. Zelensky figure as a surprise for other Ukrainian politicians due to the fact that comedian and actor was leading the polls [8; A9]. The second one was about the first round of elections [9; A6]. The third was about top three successful candidates, their programs and the forecast on the upcoming second round of elections [10; A9]. The fourth contained in-depth analysis of Volodymyr Zelensky political program, his figure as a comedian and a person with links to particular oligarch against the background of Ukrainian stand for independence because of Russian aggression and problems with corruptions within the state [11; A4]. The next story was dedicated to Ukrainian Jews' attitude to Volodymyr Zelensky as a Jew and an elected president of Ukraine [12; A4]. The report by Andrew Higgins from the city of Dnipro occupies the whole page and contains the overview of Ukrainian Jews history and couple of illustrations. The sixth, another quite a lengthy story's attention was completely concentrated on the American homeland political topic - Joseph R. Biden and possibility of Ukrainian factor's influence on his 2020 presidential campaign [13; A1, A10-A11]. And the seventh article was Andrew E. Kramer's report from Moscow about the possible implications of Igor Kolomoisky's return to Ukraine - the opposing to Petro Poroshenko's ruling team oligarch and likely shadow leader of the country after Volodymyr Zelensky's victory [14; A6].

On March $10^{\text {th }}$ the Washington Post dedicated a half of it's $6^{\text {th }}$ page (after a brief introduction on the front page) to Mr. Zelensky figure and political campaign analysis. The newspaper's correspondent Anton Troianovski managed to fill the article with a vast number of commentaries - including Ukrainian politicians, analysts and even the US Ambassador in Kyiv. The presented story contained such details as comparisons of Zelensky's campaign with cases of the US and Italy - familiar with populism as a method and comedian as a candidate. In the center of the article is Zelensky's sitcom "Servant of the People" - portrayed as one of the possible factors of his electoral success. The story is also full of details connected to local Ukrainian oligarchs and corruption, war with Russia, some reflections on other candidates and Ukrainian people readiness to feel the difference between man on the screen and real life politician $[15 ; 6]$. On April $20^{\text {th }}$ Anton Troianovski provided another report from Kyiv just before the second round of the elections. In two columns he informed the audience about the polls, influence of the Russian aggression factor on the both candidates' programs and electoral mood in Ukraine [16; 7]. On April $22^{\text {nd }}$ the same WP's correspondent reported about the Volodymyr Zelensky's victory as the new president of Ukraine, explaining why Ukrainians, tired from the war with Russia in the east, had chosen him instead of Petro Poroshenko - who was considered to be a "hero" of that war $[17 ; 1,7]$. The next day another article of Anton Troianovski appeared - on the page $11^{\text {th }}$ he reported about the first possible interior and international steps of Zelensky, due to the commentary of newly elected president's key team member $[18 ; 11]$.

Another American press reporter Georgi Kantchev has been disclosing the Ukrainian election campaign working for the Wall Street Journal. His article from March $29^{\text {th }}$ on page № A10 was about the political and economic predisposition in the country just before the first round, including revolutionary past of the state, stand against aggressive anti-Western Russia, corrupted elites and desperate people [19; A10]. Former and actual at that time US ambassadors to Ukraine helped the author to explain the situation when due to the polls there were three leading candidates with similar pro-Western rhetoric but different at the same time. In two weeks Bernard-Henri Levy's, the French philosopher's and pro-Ukrainian author's opinion after his visits to Ukraine and communication with both candidates appeared on the Wall Street 
Journal page $17^{\text {th }}$ on April $9^{\text {th }}$ [20; A17]. There he revealed his personal attitude to Petro Poroshenko and Volodymyr Zelensky portraying the first as a real hero of Ukraine and the second one - as a comic and possible populist. April $22^{\text {nd }}$ and $23^{\text {rd }}$ paper's editions were the most fruitful for Ukrainian stories. On the front page of the first one a photo of the new president of Ukraine was published and a bigger piece of Volodymyr Zelensky success story by Georgi Kantchev occupied a half of A5 page [21; A5]. There was another editorial article about new Ukrainian perspectives that day - on the A14 page: it was devoted to a key question - how young democracy under the former comedian rule is going to cope with security challenges due to Moscow's interests in the region and people's European aspirations, economy's further development and influence of local oligarchs [22; A14]. More information about Mr. Zelensky victory and his first possible steps as a president we have got from a joint article by Georgi Kantchev and Moscow WSJ correspondent Ann J. Simmons. The story appeared on the A9 page on April $23^{\text {rd }}$ and was dedicated to Russian factor analysis [23; A9]. This vector of reporters' interest was followed by another short text about Russian president Putin first probes of the new colleague in Ukraine: on April $26^{\text {th }}$ edition a small piece could be found on the page A9 [24; A9]. Ukraine was also mentioned in other WSJ stories printed in Spring 2019 and connected to natural gas trade issues [25; A1, A10], military cooperation with the US [26; A12] and situation on the eastern front - near the border with territories of Donbas region occupied by Russia-backed forces [27; A15].

The most moderate coverage of the presidential campaign in Ukraine has been demonstrated by the USA Today print version newsroom. Unlike paper's online version, always full of fresh updates from the whole world, in print there were very few articles about Volodymyr Zelensky and his path to formal political greatness. For example, on April $23^{\text {rd }}$ a small story of four sentences was compiled from stuff and wire reports on the A4 page in "In brief" section [28; A4]. On the next page a "Ukrainian" cartoon by Mike Thompson was published - comparing the results of elections with American style democracy. Actually, that picture seems to be worth more than a whole page analysis of similarity between Donald Trump 2016 and Volodymyr Zelensky 2019 runs for presidency [29; A5].

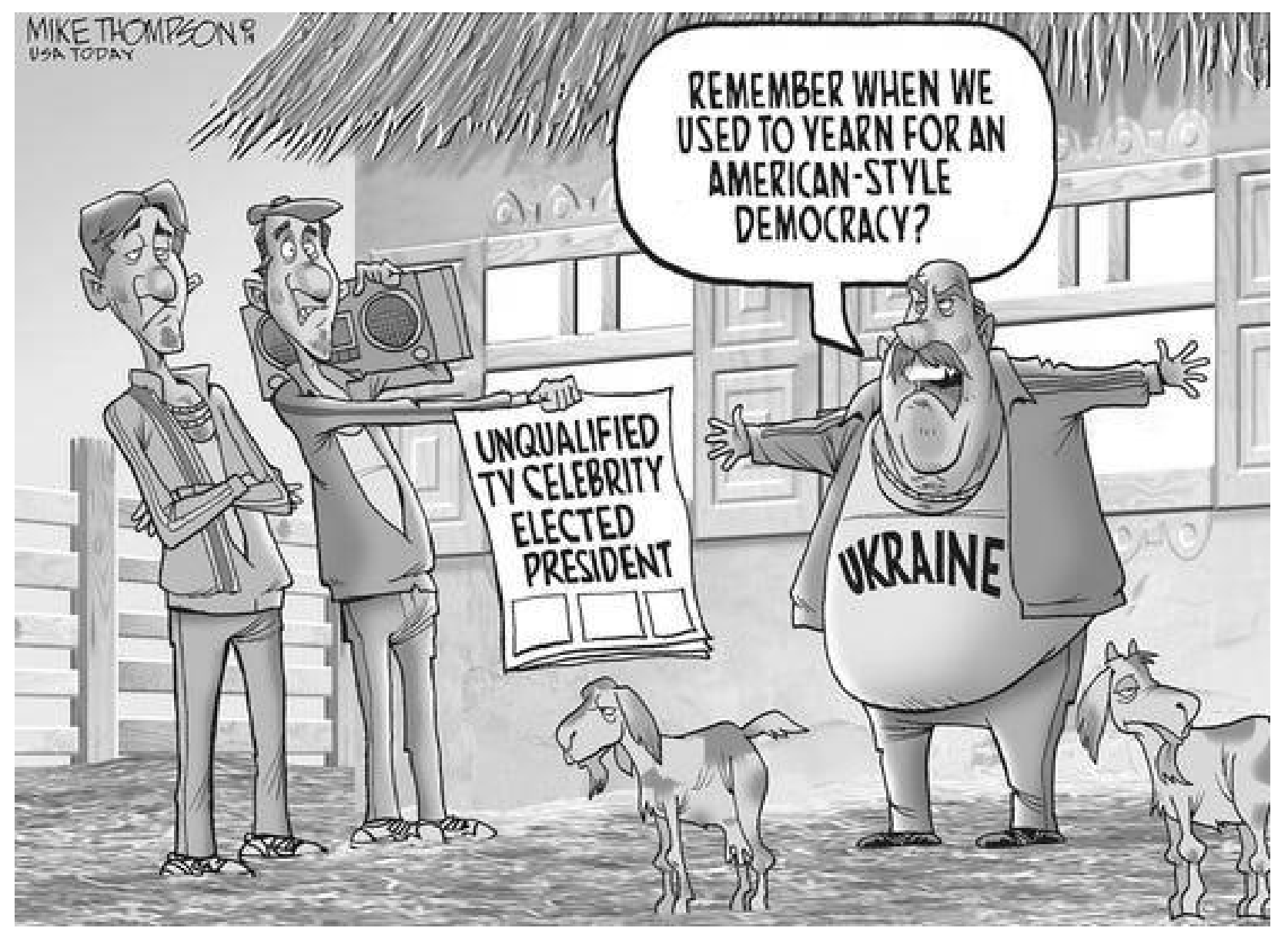


Therefore, it is a point of great interest to trace the further analysis in American press of Ukrainian elections' political outcomes for the both countries' future interactions.

\section{Every word counts}

On Monday May $20^{\text {th }}$ there were no Ukrainian president oriented stories indicated on the pages of the picked newspapers. The possible reason here might be that the local reporters and international news agencies sometimes publish the story first online and only then share its print version. There is also another explanation of the time gap between actual inauguration of the new president of Ukraine that happened that day and the appearance of the stories on the paper - the difference in time zones and obvious print process of each paper.

May $20^{\text {th }}$

\begin{tabular}{|l|c|c|c|c|c|c|c|c|c|c|}
\hline Newspaper & $\begin{array}{c}\text { Page } \\
\text { No. }\end{array}$ & $\begin{array}{c}\text { Whole } \\
\text { page } \\
\text { story }\end{array}$ & $\begin{array}{c}\text { Mention } \\
\text { in other } \\
\text { stories }\end{array}$ & $\begin{array}{c}\text { Moscow } \\
\text { report }\end{array}$ & $\begin{array}{c}\text { Local } \\
\text { report }\end{array}$ & "Kiev" & "Kyiv" & $\begin{array}{c}\text { Trump vs } \\
\text { Biden in } \\
2020\end{array}$ & $\begin{array}{c}\text { Russia: } \\
\text { Donbas or } \\
\text { Crimea } \\
\text { conflict }\end{array}$ & $\begin{array}{c}\text { Oligarchy } \\
\text { and } \\
\text { corruption }\end{array}$ \\
\hline $\begin{array}{l}\text { New York } \\
\text { Times }\end{array}$ & - & - & - & - & - & - & - & - & - & - \\
\hline $\begin{array}{l}\text { Chicago } \\
\text { Tribune }\end{array}$ & - & - & - & - & - & - & - & - & - & - \\
\hline $\begin{array}{l}\text { USA } \\
\text { Today }\end{array}$ & - & - & - & - & - & - & - & - & - & - \\
\hline $\begin{array}{l}\text { Washington } \\
\text { Post }\end{array}$ & - & - & - & - & - & - & - & - & - & - \\
\hline $\begin{array}{l}\text { Wall Street } \\
\text { Journal }\end{array}$ & - & - & - & - & - & - & - & - & - & - \\
\hline
\end{tabular}

On the next day in American print press there were much more information about Ukrainian political life. The article by Iuliia Mendel and Ivan Nechypurenko from Kyiv was placed on the 1/3 of NYT's page A9 - with first decisions of the new president after his inauguration on its focus. The first part of the report is about Volodymyr Zelensky comic path to presidency and his announcements of the parliamentary elections in July 2019 instead of October 2019 and changes in actual government. The second part was dedicated to a Russian question: president's promises to finish the conflict in Donbas region and possible negotiations with Russia on that issue. The reporters have clearly indicated the Kremlin's responsibility for the deadly war in Eastern Ukraine that is interpreted by Moscow as a "pure internal conflict". They have also mentioned the background of Crimea peninsula annexation performed by Russia. Some of the declarations made by the newly elected president during the campaign were also mentioned in the article - as an overview of his next possible steps and decrees [30; A9].

The same day the Washington Post published a smaller article on the $1 / 4$ of its A10 page. David L. Stern, Anton Troianovski and Natalia Abbakumova (two last authors contributed from Moscow) described the first political moves of Volodymyr Zelensky as a new president of Ukraine. Keeping in mind his populist type campaign, they mentioned his idea of early elections of the Ukrainian parliament, anticorruption declarations as a battle with current political establishment and tough mission to end the Donbas conflict - inspired by Russian aggressive politics. The report also contained a brief description of Volodymyr Zelensky's business activities and close ties with media and other fields of interests of oligarch Igor Kolomoisky - whose attorney (Andriy Bohdan's name is not used directly in the article) had become a key adviser of the new president. At the same time the referrals to the US home politics could be found there: particularly - the story of president's Trump personal attorney Rudolph W. Giuliani efforts to investigate the business activities of former vice president Joe Biden family members in Ukraine. However, journalists mention the reluctance of the new political elite in Kyiv to meddle with typically internal American battle for the White House [31; A10].

Simultaneously a top story of that day paper edition of the Washington Post was another Ukraine oriented topic. It was about Chinese investors' interest to Motor Sich - one of the biggest military aircraft engines producers in the world situated in Ukrainian city of Zaporizhia. Volodymyr Zelensky was 
mentioned in that far more detailed article (up to contribution directly from Kyiv, Washington and Beijing - not only from Moscow) that describes American president's administration alarm against the background of its economic and military stand with China and Russian aggression in Ukraine at the same time [32; A1, A11].

The different, shorter version of David L. Stern and Anton Troianovski report was used by the Chicago Tribune newsroom that day. On the $1 / 3$ of the paper version page 9 there was only some original passages excluded: about the new president's business experience and his close relations with local oligarch [33; A9].

On Tuesday May $21^{\text {st }}$ the Wall Street Journal reporter's in Moscow Georgi Kantchev material appeared on the $1 / 3$ of the page A8. Its key points referred to the new president's idea of early parliamentary elections, changes in the government and peace-oriented ambitions for the Eastern Ukraine still suffering from the Russian aggression [34; A8].

May $21^{\text {st }}$

\begin{tabular}{|l|c|c|c|c|c|c|c|c|c|c|}
\hline Newspaper & $\begin{array}{c}\text { Page } \\
\text { No. }\end{array}$ & $\begin{array}{c}\text { Whole } \\
\text { page } \\
\text { story }\end{array}$ & $\begin{array}{c}\text { Mention } \\
\text { in other } \\
\text { stories }\end{array}$ & $\begin{array}{c}\text { Moscow } \\
\text { report }\end{array}$ & $\begin{array}{c}\text { Local } \\
\text { report }\end{array}$ & "Kiev" & "Kyiv" & $\begin{array}{c}\text { Trump vs. } \\
\text { Biden in } \\
2020\end{array}$ & $\begin{array}{c}\text { Russia: } \\
\text { Donbas } \\
\text { or } \\
\text { Crimea } \\
\text { conflict }\end{array}$ & $\begin{array}{c}\text { Oligarchy } \\
\text { and } \\
\text { corruption }\end{array}$ \\
\hline $\begin{array}{l}\text { New York } \\
\text { Times }\end{array}$ & A9 & $1 / 3$ & - & - & + & + & - & - & + & - \\
\hline $\begin{array}{l}\text { Chicago } \\
\text { Tribune }\end{array}$ & 9 & $1 / 3$ & - & + & - & + & - & + & + & $-/+$ \\
\hline $\begin{array}{l}\text { USA } \\
\text { Today }\end{array}$ & - & - & - & - & - & - & - & - & - & - \\
\hline $\begin{array}{l}\text { Washington } \\
\text { Post }\end{array}$ & A10 & $1 / 4$ & + & + & - & + & - & + & + & + \\
\hline $\begin{array}{l}\text { Wall Street } \\
\text { Journal }\end{array}$ & A8 & $1 / 3$ & - & + & - & + & - & - & - & - \\
\hline
\end{tabular}

From May $22^{\text {nd }}$ till May $24^{\text {th }}$ we managed to find only two mentions of Ukraine in terms of newly elected president. The first one was a short abstract in the digest section of the Washington Post: five sentences of the Associated Press report were dedicated to Ukrainian lawmakers' refusal to consider Volodymyr Zelensky proposal to change the election law [35; A11]. The second article in the WSJ had no direct connection with the new Ukrainian political establishment but contained the president Zelensky's name. It was a story about a lawsuit filed by Joint Stock Co. Commercial Bank PrivatBank in Delaware against its former controlling shareholders including Ihor Kolomoisky as an actor of "loan recycling" scheme [36].

May $23^{\text {rd }}$

\begin{tabular}{|l|c|c|c|c|c|c|c|c|c|c|}
\hline Newspaper & $\begin{array}{c}\text { Page } \\
\text { No. }\end{array}$ & $\begin{array}{c}\text { Whole } \\
\text { page } \\
\text { story }\end{array}$ & $\begin{array}{c}\text { Mention } \\
\text { in other } \\
\text { stories }\end{array}$ & $\begin{array}{c}\text { Moscow } \\
\text { report }\end{array}$ & $\begin{array}{c}\text { Local } \\
\text { report }\end{array}$ & "Kiev" & "Kyiv" & $\begin{array}{c}\text { Trump } \\
\text { vs. } \\
\text { Biden in } \\
2020\end{array}$ & $\begin{array}{c}\text { Russia: } \\
\text { Donbas } \\
\text { or Crimea } \\
\text { conflict }\end{array}$ & $\begin{array}{c}\text { Oligarchy } \\
\text { and } \\
\text { corruption }\end{array}$ \\
\hline $\begin{array}{l}\text { New York } \\
\text { Times }\end{array}$ & - & - & - & - & - & - & - & - & - & - \\
\hline $\begin{array}{l}\text { Chicago } \\
\text { Tribune }\end{array}$ & - & - & - & - & - & - & - & - & - & - \\
\hline $\begin{array}{l}\text { USA } \\
\text { Today }\end{array}$ & - & - & - & - & - & - & - & - & - & - \\
\hline $\begin{array}{l}\text { Washington } \\
\text { Post }\end{array}$ & A12 & $\begin{array}{c}\text { Digest/ } \\
\text { AP }\end{array}$ & - & - & - & - & - & - & - & $-/+$ \\
\hline $\begin{array}{l}\text { Wall Street } \\
\text { Journal }\end{array}$ & - & - & + & - & - & - & - & - & - & - \\
\hline
\end{tabular}




\section{Conclusion}

1. Despite the predisposition that Ukraine is a true nightmare for a journalist, who wants to have as monosemantic story as possible [37; 92], American print media dare to cover its political life and display its details in order to inform the audience. NYT, WP, WSJ and even regional paper Chicago Tribune have demonstrated their interest to Ukrainian president's inauguration after free and democratic elections in the country under the actual war with Russian Federation as a worth reading fact for their audience. Only USA Today didn't mention the story - possibly waiting for a more obvious appeal to the American internal political issues. All newspapers except USA Today have put the Ukrainian story in common section (pages $8-10)$ and on a similar space (1/3-1/4 of the page).

2. At the same time the editorial understanding of its audience interests and actuality of the news, when it comes to international political journalism coverage, tends to be the defining matter of the life period of each story. Ukrainian new president's inauguration was not that kind of story to write about it a day before the actual inauguration and days after it. Due to the experience of earlier publications it might become even a companion for a much bigger report on a different topic but much closer to American international political, economic or other interests in case of interactions with Russia or China for example.

3. Only some articles mentioned American Presidential elections as a future event most likely to be influenced by the Ukrainian factor. Obviously, there has not been a possibility of the third impeachment case in American history or Joseph Biden's as a Democrats' candidate rating analysis - due to timing reasons. Only some papers have proposed their audience different, detailed stories about President's Trump possible rival in 2020 - Joseph Biden and corruption allegations. But that was not on the week we were focused on. That brings us to the point that these newsrooms tend to understand their readers as some kind of a stable subscribers who read thoughtfully each paper day after day to get the understanding of every story in its evolution. For online users it is easier to follow the links or search for more details and broader view on each story.

General statistics

\begin{tabular}{|c|c|c|c|c|c|}
\hline Date & $\begin{array}{c}\text { New York } \\
\text { Times }\end{array}$ & $\begin{array}{c}\text { Chicago } \\
\text { Tribune }\end{array}$ & $\begin{array}{c}\text { USA } \\
\text { Today }\end{array}$ & $\begin{array}{c}\text { Washington } \\
\text { Post }\end{array}$ & $\begin{array}{c}\text { Wall Street } \\
\text { Journal }\end{array}$ \\
\hline May 20 & - & - & - & - & - \\
\hline May $21^{\text {st }}$ & 1 & 1 & - & 1 & 1 \\
\hline May 22 $^{\text {nd }}$ & - & - & - & - & - \\
\hline May 23 $^{\text {rd }}$ & - & - & - & 0,5 & 0,5 \\
\hline${\text { May } 24^{\text {th }}}^{\text {Aggregate }}$ & - & - & - & - & - \\
\hline
\end{tabular}

4. The majority of reporters writing about Ukraine still perform their duties from Moscow not from Ukrainian capital. That might be a question of geographical, financial, historic or other reasons, but at the same time this order of things has a proper potential to influence on the perception of Ukraine as just a part of a post-soviet space with its centre in Russian capital.

5. One of the indicators justifying this assumption here might be the way American newspapers tend spell the name of Ukrainian capital - Kiev (Russian phonetics) instead of Kyiv (Ukrainian phonetics). Although the situation has been changed to some extent recently - after the Ukrainian Ministry of Foreign Affairs launched the №KyivNotKiev campaign to gain recognition for the correct spelling of the country's cities [38].

6. The essential part of publications was not reaching the profound background of the Ukrainian political, economical, cultural life, specifications of Russian-Ukrainian conflict in a long run. Such kind of deep retrospective is impossible for the print versions of the newspapers - regardless the Ukrainians' will and aspirations.

7. Such topics as Russian aggression against Ukraine, the need to overcome corruption in the country with powerful oligarchs were present in more than a half of the considered stories. That brings us to the idea of the US press stable devotion to the principle of Interpretive sufficiency [5] when it comes to 
the coverage of international issues originally far from American borders but potentially capable of becoming closer and more preeminent in the eye of national interests - as it was with the coverage of the Kerch strait conflict at the end of 2018 [1].

\section{References}

1. Abbakumova, N., Stern, D., Troianovski, A. 2019. "Entertainer elected to lead Ukraine starts with some serious messaging”, The Washington Post, May 21, 2019. P. A10.

2. Assosiated Press. 2019. "Zelensky's proposal on election law is snubbed", The Washington Post, May 23, 2019. P. Al1.

3. Christians, C. 2019, "The Ethics of Truth. In Media Ethics and Global Justice in the Digital Age" (Communication, Society and Politics, pp. 133-184). Cambridge: Cambridge University Press, 2019.

4. Cision media research. 2019, "Top 10 U.S. Daily Newspapers", January 04, 2019. Available URL: https://www.cision.com/us/blogs/2019/01/top-ten-us-daily-newspapers/.

5. Higgins, A . 2019. "Some Ukraine Jews Are Unhappy a Jew Was Elected President", The New York Times, April 25, 2019. P. 4.

6. Higgins, A . 2019. "Ukraine Challenger Is Poised to Get the Last Laugh", The New York Times, April 21, 2019. P. 4.

7. In brief. 2019. "Ukraine Comic wins almost $75 \%$ of vote in presidential election", The USA Today, April 23, 2019. P. A4.

8. Kantchev, G. 2019. "Let Down. Ukrainians Set to Vote”, The Wall Street Journal, March 29, 2019. P. A10.

9. Kantchev, G. 2019. "Ukraine Comedian Leads Exit Polls", The Wall Street Journal, April 22, 2019. P. A5.

10. Kantchev, G. 2019. "Ukraine Leader Dissolves Parliament", The Wall Street Journal, May 21, 2019. P. A8.

11. Kantchev, G., Simmons, A., 2019. "Powers Face 'New Game' In Ukraine", The Wall Street Journal, April 23, 2019. P. A9.

12. Karmanau, Y. 2019. "Exit poll: Comedian leads in the $1^{\text {st }}$ round of Ukrainian election", Chicago Tribune, April 1, 2019. P. 9.

13. Kramer, A . 2019. "Alarm Raised in Ukraine With Return of Oligarch", The New York Times, May 17, 2019. P. A6

14. Kramer, A . 2019. "He Plays a President on Ukrainian TV. Now Guess What?", The New York Times, March 17, 2019. P. 9.

15. Levy, B.-H. 2019. "The Comedian vs. the Hero of Ukraine”, The Wall Street Journal, April 9, 2019. P. A17.

16. Lauren, A.-L. 2013, "The Unknown Price of Freedom. The Democratic Revolutions in Georgia, Ukraine, and Kyrgyzstan. Lviv, 2013. 148 p. P. 92.

17. MacFarhquuar, N., Mendel, I. 2019. "Comedian in Ukraine Leads in Firs Round of Presidential Election”, The New York Times, April 1, 2019. P. A6.

18. MacFarhquuar, N., Mendel, I. 2019. "Comic vs. Chocolate King in Ukraine Vote Runoff”, The New York Times, April 2, 2019. P. 9.

19. Marson, J. 2019. “U.S. Strengthens Ukraine's Navy”, The Wall Street Journal, March 12, 2019. P. A12.

20. Mendel, I., Nechypurenko, I. 2019. "Ukrainian President Immediately Calls a Snap Election", The New York Times, May 21, 2019. P. A9

21. Mendel, I., Vogel, K. 2019. "For Biden, a Ukraine Matter That Won't Go Away", The New York Times, May 2, 2019. P. Al-A10.

22. O'Neal, A. 2019. “On the Russian Front in Ukraine”, The Wall Street Journal, April 26, 2019. P. A15. 
23. Opinion. No author. 2019. "Ukraine Presidential Gamble”, The Wall Street Journal, April 22, 2019. P. A14.

24. Pancevski, B. 2019. "Russian Gas Plan Divides U.S., Allies”, The Wall Street Journal, March 11, 2019. P. A1-A10.

25. Romanyshyn, Y. 2018, "№KyivNotKiev campaign asks foreign media to change their spelling of Ukraine's capital”, Kyiv Post, October 2, 2018. Available URL: https://www.kyivpost.com/ukrainepolitics/kyivnotkiev-campaign-asks-foreign-media-to-change-their-spelling-of-ukraines-capital.html.

26. Scurria, A. 2019, "Lawsuit filed in Delaware accuses country's oligarchs of 'loan recycling' scheme”, May 23, 2019. Available URL: https://www.wsj.com/articles/ukraines-privatbank-sues-itsformer-owners-11558645915.

27. Simmons, A. 2019. "Putin Offers a Carrot To President-Elect", The Wall Street Journal, April 26, 2019. P. A9.

28. Sonmez, F. M. 2019. "Biden claims he newer acted inappropriately", Chicago Tribune, April 1, 2019. P. 8.

29. Stern, D., Troianovski, A. 2019. "Ukraine TV star takes office, this time for real”, Chicago Tribune, May 21, 2019. P. 9.

30. Troianovski, A. 2019. "Cash-hungry Ukraine embraces China", The Washington Post, May 21, 2019. P. A1-A11.

31. Troianovski, A. 2019. "Comedian expected to be next Ukrainian president", The Washington Post, April 20, 2019. P. A7.

32. Troianovski, A. 2019. "He Plays a President on Ukrainian TV. Now Guess What?", The Washington Post, March 10, 2019. P. A6

33. Troianovski, A. 2019. "Ukraine picks TV president to be real one", The Washington Post, April 22, 2019. P. A1-A7.

34. Troianovski, A. 2019. "Television president faces the reality of ruling Ukraine", The Washington Post, April 23, 2019. P. A11.

35. Zaliznyak, Y. 2016, Information security and Russian aggression: Ukraine-EU-NATO hybrid response to hybrid war, Yearbook of the Institute of East-Central Europe, vol. 14, no. 2, 2016, pp. 23-42.

36. Zaliznyak, Y. 2019, "Peculiarities of the American Print Media Coverage of RussianUkrainian Conflict in the Kerch Strait of 2018." Visn. Lviv. Univ., Ser. Zhurn. 2019: 46; 252-264 DOI: http://dx.doi.org/10.30970/vjo.2018.44.9326.

37. Zaliznyak, Y. 2017, "Russian world's fundamentalism aggression against Ukraine as a challenge for modern journalism standards": Polityka i Społeczeństwo, vol. 1 (15), Rzeszów University, 2017, pp. 171-184. 